\title{
Stanford's Summer Research Program for Teachers Long-Term Outcomes Study
}

\author{
Kaye Storm ${ }^{1}$ and Gary Lichtenstein ${ }^{2}$
}

\author{
${ }^{1}$ Stanford University, Stanford, CA; ${ }^{2}$ Quality Evaluation Designs \\ Keywords: Teacher Professional Development, Research Experiences for Teachers, RET \\ Publication Date: January 30th, 2019 \\ DOI: https://doi.org/10.15695/jstem/v2i1.04
}

\begin{abstract}
Research Experience for Teachers (RET) programs have been placing K-12 teachers in university research labs for almost three decades (Pop et al., 2010). However, the long-term impacts are rarely explored. This paper summarizes data from a survey study of 135/158 teachers (88\% response rate) who participated in Stanford University's RET programs between 2005 and 2017. The purpose of the study was to gauge the lasting impact of RET, if any, on teacher retention and classroom and professional practices. The data strongly suggest that participants gain long-lasting personal and professional benefits from participation--value that seems to be especially magnified for mid- to late-career teachers who are well established in their teaching practices but committed to continuous improvement. Furthermore, if the self-reports are accurate, these results would presumably also accrue to teachers' students. Findings are attributed to the efficacy of the RET model. The authors argue for a nationwide evaluation of the efficacy of RET for teacher retention and professional development.
\end{abstract}

\section{INTRODUCTION}

Research Experience for Teachers (RET) programs have been placing K-12 teachers in university research labs for almost three decades (Pop et al., 2010). An important goal of these programs is to provide STEM teachers with discovery and technology-based learning experiences, which will then be incorporated into their classroom activities during the school year (NSF, 2011). Evaluations of RET programs have been consistently positive. However, the long-term impacts of RET are rarely explored. This paper summarizes data from a survey study of 158 teachers who participated in Stanford University's RET programs between 2005 and 2017. The purpose of the study was to gauge the lasting impact of RET, if any, on teacher retention and classroom and professional practices.

\section{BACKGROUND AND CONTEXT}

The Summer Research Program for Teachers is operated by Stanford's Office of Science Outreach (OSO) and supported by the Vice Provost and Dean of Research. Stanford science and engineering faculty hosted 158 individual teachers in 256 research experiences between 2005 and 2017. Over half $(62 \%)$ participated for two consecutive years. Almost two-thirds (63\%) of these placements were funded by the National Science Foundation (NSF) through three Research Experiences for Teachers (RET) Site awards (Dr. Sheri Sheppard, PI), faculty CAREER awards, RET Supplements, and other NSF awards to Stanford research centers and principal investigators.

Teachers are eligible to participate in Stanford's RET if they: (a) currently teach STEM in grades 7-14 in the San Francisco Bay Area; (b) have completed at least two full years of teaching; (c) commit to teaching for at least three years following their RET participation; (d) obtain their principal's recommendation; and (e) hold U.S. citizenship or are permanent residents. Stanford partners with Ignited (http://www.igniteducation.org/), an educational nonprofit with over three decades of experience in placing STEM teachers in industry and research laboratories. Ignited is responsible for initial teacher recruitment and has a strong school network that results in two or three times as many applicants as there are available placements. Each host Principal Investigator (PI) receives 4-6 applications of candidates whose background and interests match the skills required by the PI's project. PIs (often with their graduate student mentors) then interview at least one candidate and make the final selection decision. During the 8-week summer program, 
teachers work in their individual labs four days per week and spend one day each week in programming arranged by Stanford's Office of Science Outreach. These weekly group meetings feature faculty lectures and lab tours to give participants a glimpse of the innovative STEM research taking place on campus and help create a strong Professional Learning Community for the teacher cohort. Ignited staff and coaches (veteran teachers and alumni of Stanford's RET program) provide an infrastructure and pedagogical support to help teachers translate elements of their research project into innovative and effective curriculum and then share it broadly with other educators. Ignited also disseminates the new curriculum widely.

\section{LITERATURE REVIEW}

Evaluations of RET programs have been consistently positive (Russell et al., 2007; Dubner et al., 2001; Westerlund et al., 2002). However, the long-term impacts of RET, including their effect on teacher retention, are rarely explored.

Data are mixed on the effects of teacher attrition on student achievement. Some studies show that those who leave are less effective teachers, but the picture is murky, because teacher attrition is associated with lower student achievement. It is also difficult to calculate because some teachers who leave the classroom later return to teaching after a break (Adnot et al., 2017; Boyd, 2008; Lindqvist et al., 2014). What we do know is that teacher attrition brings with it huge costs, not the least of which are financial (Watlington et al., 2010). Yet assessing teacher retention of RET alumni over time is difficult, due to challenges in tracking alumni and in linking the reasons for retention or attrition to the teachers' RET experiences. The University of Arizona Teachers in Industry (UATIA) program, with a sample size of 160 and Industry Initiatives for Science and Math Education (IISME), with a sample size of 734 , have conducted teacher retention studies showing much higher than average retention among their participants (Buxner, 2018; Weisbaum et al., 2001). Typically these programs were six to eight weeks long and focused on workforce development. Therefore, they placed teachers primarily in corporations and, to a lesser degree, university research labs. Teachers earned professional development credits in both programs. The Arizona program also offered intensive coursework leading to a Master's Degree in Teaching and Teacher Education for teachers who wanted to undertake that. Annual attrition rates of their participants were calculated to be between $3.5 \%$ and $4.0 \%$ annually, compared with the national and California attrition rates of $8 \%$ at the time of the IISME study.

Little has been written on the intermediate- or long-term effects of RET on teachers' classroom practices. Pop et al. (2010) contacted 73 of 90 (81\%) K-12 teachers who participated in a 6-week university lab-based RET program be- tween 1999 and 2006. A major focus of the study was to determine in what ways elementary teachers differ from middle/secondary teachers with respect to their motivation for participating in a RET program and the ways in which they implement changes to their teaching practices after their RET experience. Respondents completed three surveys, including a Changes to Teaching Practices Questionnaire. A total of 67 of 73 teachers responded ( $92 \%$ response rate). Of those, 12 were interviewed. On average, teachers agreed that RET prompted changes in their teaching practices; made them more student-centered; and spurred them to do more hands-on activities, incorporate more experiments into their lessons, and add activities requiring students to apply science in real life situations. Results were significantly higher for elementary teachers than middle and high school teachers. Yet all teachers agreed that participation in RET made them more excited about further professional development.

Autenrieth et al. (2017) conducted a long-term study of 150 teachers who participated in a Texas A\&M engineering RET program between 2003 and 2013. However, the response rate was low (21\%) and except for some quotes, data are not provided. The authors report that the most frequently cited benefits of participation are: (a) an improved understanding of engineering, (b) the opportunity to collaborate/ network with other teachers, (c) positive effects on teaching style/approach, and (d) a renewed feeling of energy when returning to the classroom (p. 27).

Research into RET programs has documented how RET participation promotes student-centered, inquiry-oriented, active learning pedagogies (Enderle et al., 2014; Herrington et al., 2016; Klein-Gardner et al., 2012). Inquiry-based teaching is strongly recommended by the American Association for the Advancement of Science (AAAS, 1994) and the National Research Council (NRC, 1996, 2000) as a strategy to develop deeper student understanding of science to apply to the everyday world. These reform documents clearly recommend that teachers should be spending more time using inquiry-based instructional strategies in problem-solving contexts, and less time in didactic presentations of facts (Southerland, et al. 2003). Bybee (2004, p. 9) suggests, "Inquiry as a teaching strategy should capture that spirit of scientific investigation and the development of knowledge about the natural world."

Yet studies suggest that most teachers have little experience with inquiry in a formal, scientific sense, and thus possess very naive and informal conceptions of inquiry and inquiry oriented learning in the classroom (Blanchard et al., 2009; Windschitl, 2004). Although NSF does not expressly advocate that RET programs promote inquiry learning, published studies and program evaluations often indicate that a propensity towards active- and inquiry-oriented learning are outcomes of teachers' RET experiences (Westerland, 2002; Klein-Gardener et al., 2012; Herrington et al., 2016; Pop et 
al., 2010).

Since its inception, the Stanford RET program, like most other RET programs, has been evaluated using pre- and post-program surveys of teachers and graduate student mentors, as well as by external evaluator Quality Evaluation Designs, and by our educational partner, Ignited. Although annual post-program evaluations have indicated that teachers' experiences motivate them to engage in more hands-on, inquiry-oriented learning, we wanted to explore long-term effects of participation. We conducted a survey study to explore the following research questions:

- Research Question \#1: Does participation in a Research Experience for Teachers (RET) program affect teacher retention in the classroom, and if so, how?

- Research Question \#2: Does RET participation impact teachers' pedagogical approach, and if so, in what ways?

- Research Question \#3: Does RET participation result in changes in teachers' attitudes and professional practices, and if so, in what ways?

\section{METHOD}

In January 2018, an online survey was sent to 154 of 158 program alumni who participated in Stanford's RET program between 2005 and 2017. Four program alumni, 2.5\%, could not be located and did not receive the survey. The survey was comprised of three sections. The first part asked questions related to teacher retention. Pedagogy questions were included in section two of the survey, divided into two sub-sections. First, teachers were asked whether and how RET influenced their pedagogical approach. Second, teachers were asked whether and how RET influenced their professional practices and attitudes. The final section of the survey was comprised of demographic questions.

\section{RESULTS}

I. Characteristics of Teachers Responding. Of the 154 alumni who received the survey, 135 responded, yielding an $88 \%$ response rate. Survey respondents represented or last taught in 125 schools (99 public, 26 charter or private) in 45 districts in the San Francisco Bay Area. One-third taught in Title I schools (i.e., schools with at least $40 \%$ of students eligible for Free or Reduced Price Meals). RET alumni are representative of teacher demographics throughout the region. Over half (54\%) are female. High school STEM teachers in the five-county area closest to Stanford are still predominantly white or Asian; only $12 \%$ are African American or Latinx (California Department of Education, 2018). RET alumni reflect this ethnic representation; $15 \%$ are African American or Latinx.
The large majority of survey respondents were or are high school science teachers with at least eleven years of teaching experience. As seasoned professionals, the fact that they consistently report altering their professional practices because of their RET participation is noteworthy. Teacher characteristics are displayed in Table 1.

Table 1. Teacher Characteristics

\begin{tabular}{lcc}
\hline $\begin{array}{l}\text { Years of Teaching }(\mathbf{n}=\mathbf{1 3 5} \\
\text { total respondents) }\end{array}$ & $\#$ & $\mathbf{\%}$ \\
\hline $1-3$ years & 1 & $1 \%$ \\
$4-7$ years & 20 & $15 \%$ \\
8-10 years & 21 & $16 \%$ \\
$11-15$ years & 34 & $25 \%$ \\
16 or more years & 59 & $44 \%$ \\
\hline
\end{tabular}

\section{Grade Levels Currently Teaching $(\mathrm{n}=107 \text { still teaching })^{1}$}

\begin{tabular}{lcc}
\hline High School & 86 & $81 \%$ \\
Middle School & 12 & $11 \%$ \\
Elementary School & 2 & $2 \%$ \\
Community College & 9 & $8 \%$ \\
University/Adult Education & 2 & $2 \%$ \\
\hline
\end{tabular}

Subject(s) Currently Teaching $(\mathrm{n}=107 \text { still teaching })^{1}$

\begin{tabular}{lcc}
\hline Science & 87 & $81 \%$ \\
Math & 10 & $9 \%$ \\
Computer Science & 6 & $6 \%$ \\
Engineering & 5 & $5 \%$ \\
All STEM Subjects & 4 & $4 \%$ \\
Humanities & 4 & $4 \%$
\end{tabular}

${ }^{1}$ Totals more than $100 \%$ since some teachers teach multiple grade levels or subjects.

We calculated demographics of non-responding teachers based on their RET applications to determine if they differed demographically in any significant way from respondents. Although we hypothesized that there might be differences based on the number of years of teaching experience or the year(s) in which teachers participated in the program, we found no notable differences in demographic characteristics of responders compared to non-responders.

II. Teacher Retention. Research Question \#1: Does participation in a Research Experience for Teachers (RET) program affect teacher retention in the classroom, and if so, how? Given long-standing concerns about the low number of STEM teachers being prepared in credentialing programs and the high teacher retirement and attrition rates, this 2018 study of Stanford's RET Program measured the retention of its participants in the classroom. We asked respondents a number of questions about their current employment status to calculate this rate. In addition to data collected from 
respondents, Office of Science Outreach staff were able to confirm employment for all RET program alumni who did not complete the survey, with the exception of the four individuals who could not be located. Employment was verified via school websites, school/district personnel, or social media. Thus, the teacher retention figures in Table 2 assume the four alumni who could not be found have left teaching.

Table 2. Current Status of Program Alumni

\begin{tabular}{lcc}
\hline Employment Status of Program Alumni & $\#$ & $\mathbf{\%}$ \\
\hline $\begin{array}{l}\text { Still in classroom } \\
\begin{array}{l}\text { Still in education-related profession, but not } \\
\text { classroom teacher }\end{array}\end{array}$ & 122 & $77.2 \%$ \\
No longer in education $^{2}$ & 11 & $6.9 \%$ \\
Unknown/could not be located $^{\text {TOTAL }}$ & 21 & $13.3 \%$ \\
\hline
\end{tabular}

${ }^{1}$ Five are school/district administrators, four are education consultants or professional development providers, and two are earning an Ed.D. or Ph.D. in education. 'Ten are retired, seven are working in industry or self-employed, and four are temporarily out of the workforce.

We found $77 \%$ of RET alumni are currently classroom teachers, and an additional 7\% have left the classroom but are still working in education-related professions or pursuing advanced degrees in education. Over the 12-year period of the program, this is equivalent to an average annual attrition rate from teaching of $3.5 \%$ and from education-related careers of $2.4 \%$. These averages compare favorably with the estimated annual average U.S. teacher attrition rate of $7 \%-8 \%$ over the past decade (National Center for Education Statistics, 2015) as well as the 7\% attrition rate for STEM teachers (Carver-Thomas, et al., 2017). They are also consistent with those reported in a 2001 study conducted by Industry Initiatives for Science and Math Education (now Ignited) of 734 teachers who held 8-week summer Fellowships (Weisbaum et al., 2001) and a more recent study of 160 alumni of the University of Arizona's Teachers in Industry Program (Buxner, 2018). Table 3 provides a comparison of these studies, along with national estimates.

Historically it has appeared that teachers who apply to spend a summer doing research in a Stanford laboratory are committed teachers who have the confidence and motivation to partner with research scientists at a premier university. But even those teachers must re-visit their decision to stay in teaching throughout their careers. So the question of whether RET participation promotes teacher retention is an important one.

The overall alumni attrition rate from education over 12 years is $23 \%$; from classroom teaching it's $16 \%$. This attrition rate over 12 years is similar to one reported in a 2015 National Center for Education Statistics study that included data from a five-year period. That report found that $10 \%$ of new teachers in 2007-08 did not return to the classroom the following year, increasing cumulatively to $12 \%$ in year
Table 3. Teacher Attrition Rate Comparisons

\begin{tabular}{|c|c|c|}
\hline Population Studied & $\begin{array}{l}\text { Average Annual } \\
\text { Attrition Rate }\end{array}$ & Time Period \\
\hline $\begin{array}{l}\text { Stanford Summer Research } \\
\text { Program for Teachers }(n=158)\end{array}$ & $3.5 \%$ & $2005-2017$ \\
\hline $\begin{array}{l}\text { Industry Initiatives for Science } \\
\& \text { Math Education/Ignited }{ }^{1} \\
(n=734)\end{array}$ & $4.0 \%$ & $1985-2001$ \\
\hline $\begin{array}{l}\text { Arizona Teachers in Industry } \\
\operatorname{Program}^{2}(n=160)\end{array}$ & $3.6 \%$ & $2009-2018$ \\
\hline $\begin{array}{l}\text { All STEM Teach- } \\
\operatorname{ers}^{3}(n=285,000)\end{array}$ & $7.2 \%$ & 2011-2012 \\
\hline $\begin{array}{l}\text { All U.S. Teachers }{ }^{4}(n=3.4 \\
\text { million })\end{array}$ & $7.0 \%$ & $1988-2013$ \\
\hline
\end{tabular}

three, $15 \%$ in year four and $17 \%$ in the fifth year (Gray et al., 2015).

In the current study, of 135 respondents (including those who ultimately left teaching), 113 (84\%) said their RET participation was a factor in increasing their commitment to stay in teaching. These respondents reported that many aspects of the program had this effect; on average, four program characteristics were selected by each teacher as salient factors. Figure 1 displays the factors teachers could select and their respective responses.

Figure 1. RET Experience Related to Commitment to Stay in Teaching

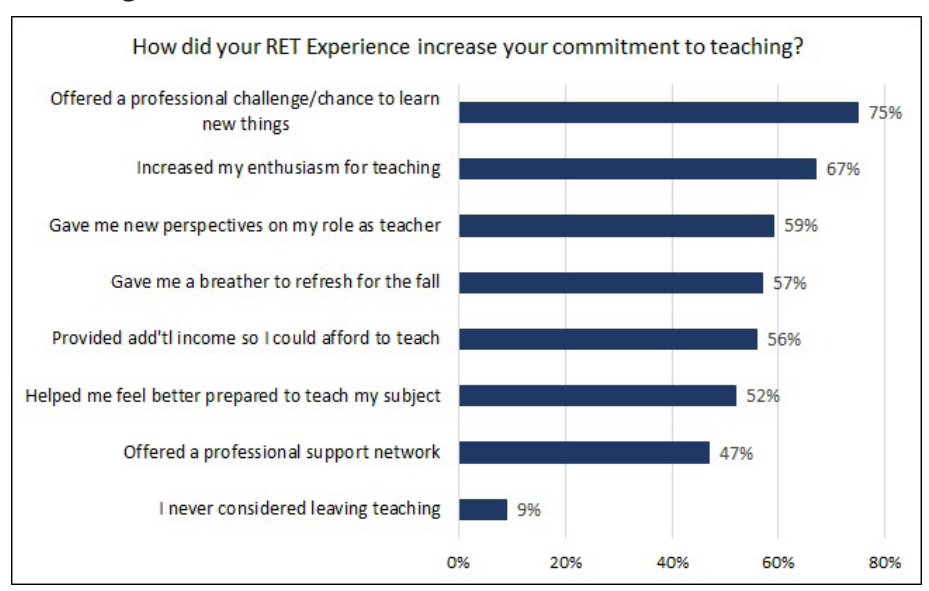

What about the "leavers" and their longevity in the classroom? Not surprisingly, the highest proportions of "leavers" clustered at both ends of the spectrum-34\% of the "leavers" retired after more than 20 years of teaching and $28 \%$ were comparatively new teachers, with fewer than seven years of teaching experience. The alumni who responded to the survey but are no longer classroom teachers were asked if the RET experience contributed to their decision to leave classroom teaching, and if so, how. Two-thirds said "No" but $32 \%$ said "Yes." Of the $32 \%$ who said that their RET experi- 
ence contributed to their departure from the classroom, $21 \%$ reported that RET motivated them to earn advanced degrees or become school administrators (see Table 4).

Table 4. RET Experience Related to Decision to Leave Teaching

\begin{tabular}{lcc}
\hline $\begin{array}{l}\text { Did your RET Experience contribute to your } \\
\text { decision to leave classroom teaching in any of } \\
\text { these ways? (Check only one.) }\end{array}$ & $\#$ & $\mathbf{\%}$ \\
\hline $\begin{array}{l}\text { No, the experience was not a factor. } \\
\begin{array}{l}\text { Yes, it made me want to pursue more education/ } \\
\text { an advanced degree. }\end{array}\end{array}$ & 3 & 19 \\
$\begin{array}{l}\text { Yes, it made me want to pursue a career as a } \\
\text { school administrator. }\end{array}$ & 3 & $10.7 \%$ \\
$\begin{array}{l}\text { Yes, it expanded my skills to make me more } \\
\text { employable in another career. }\end{array}$ & 2 & $7.1 \%$ \\
$\begin{array}{l}\text { Yes, it made me feel more respected and valued. } \\
\text { Total }\end{array}$ & 1 & $3.6 \%$ \\
\hline
\end{tabular}

The final survey question offered respondents the chance to share any thoughts about how their RET experience impacted their decision to stay in or leave classroom teaching. Many respondents testified that the RET experience enhanced their job satisfaction, as seen in these representative quotes:

I didn't really see how I was going to grow as a teacher before doing my first Stanford RET in 2007. Now I can't see anything but room for growth. I have many ideas now about what I can do to grow as a teacher. I am more knowledgeable about where to look for help and resources. I take more classes even though I am at the top of the salary scale. And I am more resilient, knowing that if a new approach in my classroom doesn't go well at first, within a few tries my new techniques will improve. Lastly, I have always encouraged students, but I am now much more convinced of their ability to eventually conquer their math/science learning challenges than I used to be. And that makes me take their failures less seriously and their successes more seriously. I gained this perspective from my own learning experiences in my Stanford Fellowships.

Stanford's RET provided many opportunities for me to develop new skills, hone old ones, meet Nobel Laureates, partner with colleagues, work with researchers, and grow by leaps and bounds as a teacher/professional and person.

The biggest long-term impact of my RET has been a continually growing network of colleagues with whom I interact. This extended community is in some ways more important to me than my school colleagues and has kept me engaged and learning.

The RET rekindled my love of science and exploration, fairness and rational thought, which, in some sense, kept my little boat afloat while bucking the waves of failed school reform efforts and changing trends in education, year after year.
Teachers who had left the classroom but stayed in education cited the transformational nature of their RET experiences:

My Stanford RET gave me a window into what full time curriculum development might look like, which confirmed for me how much I enjoy that aspect of teaching. Leaving the classroom was a difficult decision, but I now write curriculum, which is my dream job.

The RET allowed me to further develop my leadership skills so that I'm now assistant principal of a high school. In this new position I'm committed to ensuring that students receive a quality education in science, one which emphasizes inquiry.

I wanted to assume a leadership role to ensure that students were exposed to authentic science, so now I'm a school administrator. My two research experiences gave me the confidence to pursue a position as principal of a Chicago public school.

Even respondents who had left education altogether had positive things to say about the program's impact:

Being an educator is something I can never walk away from. I hope to go back to the classroom when my kids are older. My RET experience at Stanford is something that will never be replicated! I wish every state could have such a program.

I am working for an ed-tech start-up and very active in education reform. This was definitely inspired by my RET experience.

The RET experience motivated me to advance my career as a woman in STEM.

It was my personal decision to try a new career and challenge myself. I still tutor students and will continue to be an informal educator.

III. Changes in Pedagogical Approaches. Research Question \#2: Does RET participation impact teachers' pedagogical approaches, and if so, in what ways? Respondents were asked how they drew on their RET experience(s) in their classroom planning and instruction. They could select as many options as they wished; on average 3.5 strategies per teacher were selected. No respondents selected "None." Results are displayed in Figure 2.

Respondents were also given the opportunity of elucidating their responses with this prompt: "Feel free to share any thoughts about how your RET experience(s) impacted your classroom teaching." Comments included:

The experience gave me confidence to teach topics I had little previous knowledge of and develop some really cool labs. Additionally, I developed a new course in which students complete their own research projects. I didn't have the research skills to lead such a class before my RET experience. 
Figure 2. How RET Impacts Classroom Practice

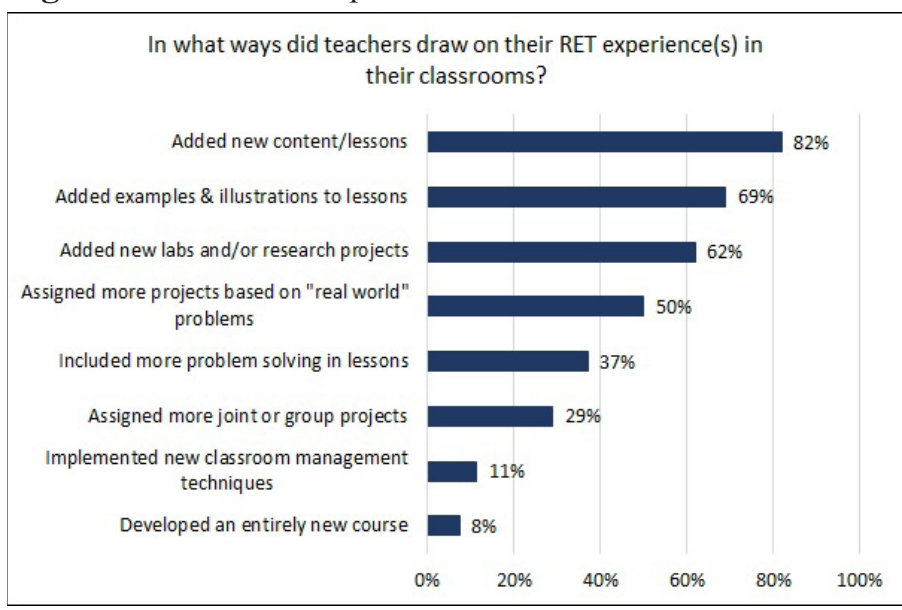

It increased the depth and breadth of my scientific knowledge as well as my understanding of research practices. I also felt much better prepared to speak to students about skills and expectations for college readiness.

It gave me time to discuss and think about how to target and address science-based misconceptions in the classroom.

The experience rejuvenated my enthusiasm for chemistry and gave me new ideas for how to pique my students' interest in science.

The experience fueled my enthusiasm for sharing with my students, and it's that energy that students always say is the best and most motivating part of my courses.

Being a RET participant gave me the confidence to start my own biotechnology class. It was an amazing experience that encouraged me to continue working with professionals at Stanford. I'm still exposed to their day-to-day research activities, which helps me tremendously when I explain how protocols work to my students.

To reflect on changes in their teaching practice in the years after their RET experience, respondents were asked how frequently they required their students to complete certain types of assignments or perform tasks in a particular way. Two of the activities are explicitly Next Generation Science Standards (Developing and Using Models and Using Mathematics and Computational Thinking). The others align with the Grades 9-12 "condensed practices" (National Research Council, 2012). There were two identical survey questions. In the first they estimated how frequently they incorporated certain strategies in their teaching before their participation; in the second they were asked to compare that with current teaching practice (or practice at the time they left the classroom). Figure 3 shows the extent to which teachers changed the "before-after" frequency in which they engaged in these pedagogical practices. Notably, teachers reported that each pedagogical strategy was used with increased frequency: "rarely" became "monthly," "monthly" became "weekly," and so on. T-tests indicated all comparisons are statistically significant at $\mathrm{p}<.001$. This means that according to teacher self-reports, the program caused teachers to use these critical pedagogies more frequently after the program than before.

One best practice and predictor of the extent to which teachers are satisfied with their RET experience and use it as a catalyst to make desired changes to their teaching practice is the frequency with which they keep in touch with their faculty hosts, mentors, program staff and each other (Russell et al., 2007). Russell et al.'s SRI study, commissioned by the NSF, found the greater these contacts after the program, the more highly the teachers rated their experience. Therefore, the Stanford survey asked in what ways teachers stayed in communication with Stanford and each other after their RET experience. Teachers checked an average of 3.3 different ways they stayed in touch with the program. Results are displayed in Figure 4.

Figure 3. Teaching Practices Before and After RET

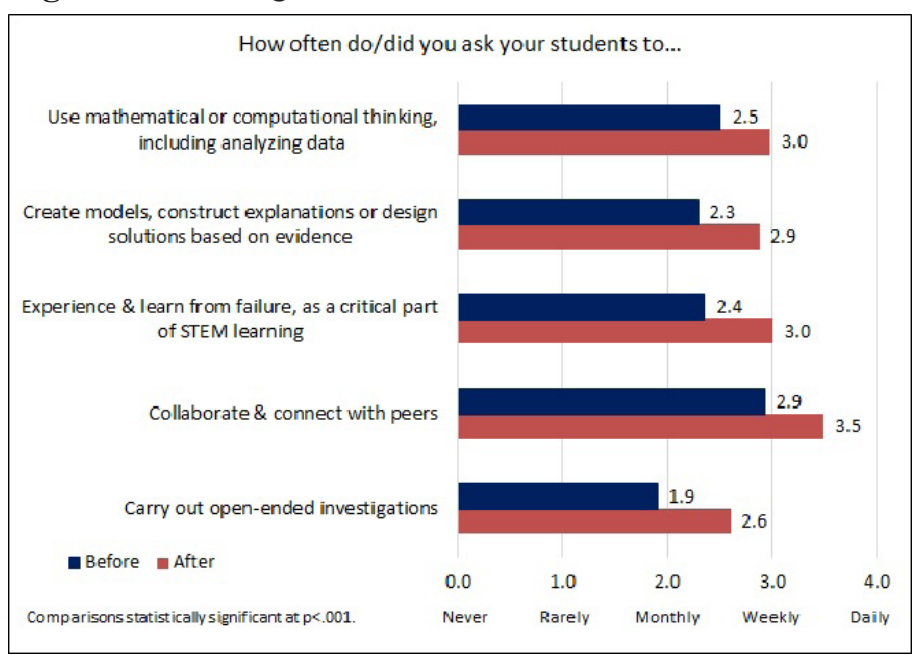

Figure 4. Staying in Touch After RET Program

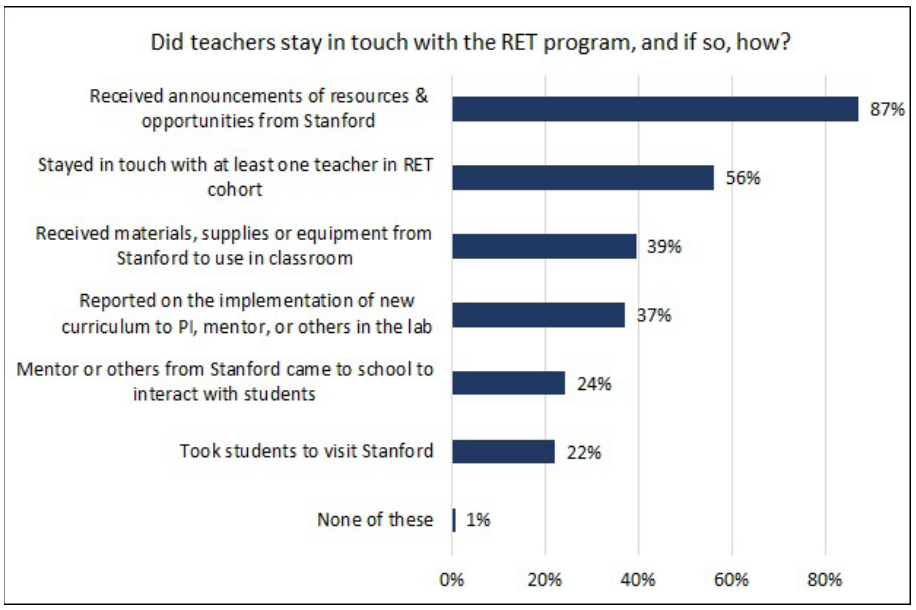

IV. Changes in Attitudes and Professional Practices. Research Question \#3: Does RET participation result in changes in teachers' attitudes and professional practices, and if so, in what ways?. We were curious whether teach- 
ers' attitudes changed about any aspect of their teaching as a result of their participation in the program. Addressing attitudes was not a specific intention of the program, nor were these attitudes explicitly discussed during the summer, but teachers have been sharing anecdotes related to attitudinal changes for many years, so we decided to ask specifically about them. Results are displayed in Figure 5.

Figure 5. Attitudinal Changes Since RET

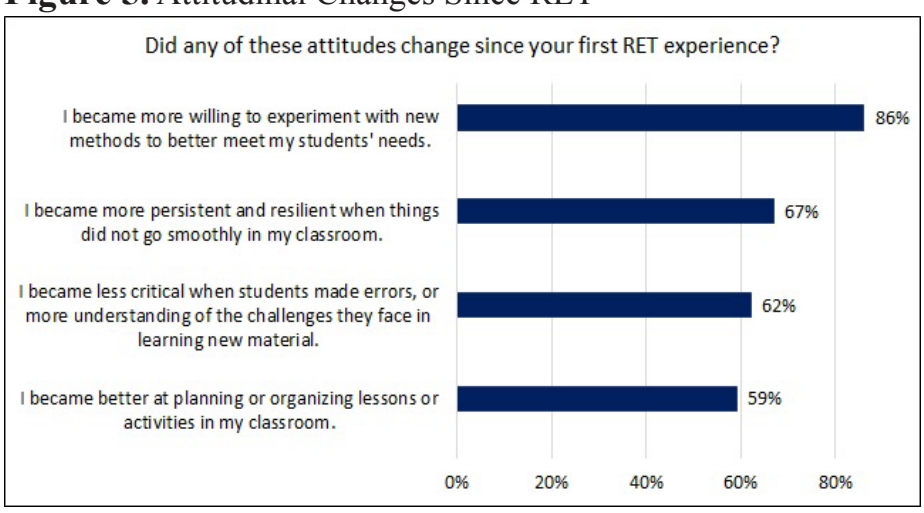

Respondents were asked what professional activities they had participated in since their first RET experience. The authors were curious about the extent to which teachers assumed more leadership roles within their school setting or pursued additional professional opportunities. They could select as many options as they wished; on average 2.2 items per teacher were marked; $8 \%$ selected "None." It was beyond the scope of this study to determine if these professional practices were stimulated by or increased as a result of the teachers' RET experiences. Results are displayed in Figure 6.

Figure 6. Professional Development Activities Since RET

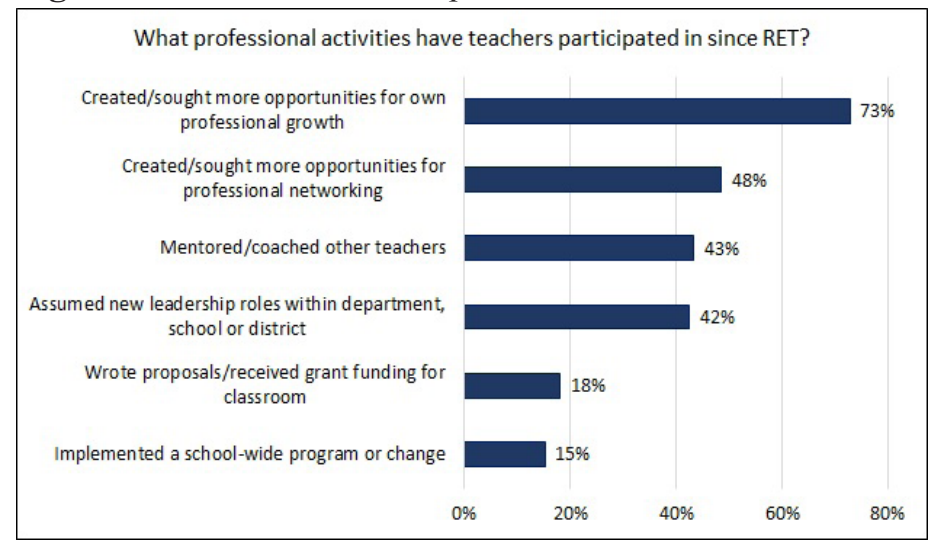

V. Summary and Implications. In this study, we explored the effects of the Stanford RET program on teacher retention, pedagogical approaches, and attitudes and professional practices. We were able to track teacher retention data for 154 of 158 program alumni. Of those responding, $77 \%$ were still in the classroom, with another $7 \%$ still in an education-related field. The relatively low annual attrition rate among RET participants compares favorably to state and national trends and allays concerns that RET programs help usher teachers out of the classroom. While comparisons of teacher retention are imperfect, it is clear from this study that teachers appreciate the professional challenge/opportunity to learn new things ( $75 \%$ of respondents) offered by Stanford's RET and consider their increased enthusiasm for teaching (67\% of respondents) a very positive outcome.

Teachers' self-reported effects of RET on their pedagogical practices are particularly noteworthy. Two of the strategies were Next Generation Science Standards (NGSS). The other three align with NGSS Grade 9-12 "condensed practices." (National Research Council, 2012). All Stanford RET alumni reported that prior to the program they used, on average, four of five progressive pedagogies weekly. After RET, three of those four pedagogies were increased, on average, to daily use. The most dramatic shift among them was Collaborate and Connect with Peers, which increased by $20 \%$. Teachers' before/after reflections related to the fifth progressive practice, Carry Out Open-Ended Investigations, increased $37 \%$, shifting from monthly to weekly use. These are dramatic increases that suggest strong and lasting classroom effects with the potential to significantly impact student learning.

In the area of attitudes and professional practices, the greatest changes were in two areas. Nearly $90 \%$ of teachers $(86 \%)$ report greater willingness to experiment with new teaching methods to meet the needs of students. This finding aligns with the significant increase teachers report in their use of open-ended investigations. Also, $73 \%$ of teachers reported that they created/sought a range of professional development opportunities following their RET experience. These are notable outcomes of the RET summer program.

Although we had a very high response rate, it is important to acknowledge that all data are self-reported. This is a limitation of the study. Stanford RET alumni are clearly enthusiastic about the program; many participated multiple times. Teachers may have over-reported program benefits and/or conflated RET outcomes with those of other professional development activities.

In spite of these limitations, data strongly indicate that the Stanford RET program increased teachers' retention and resulted in - or at least strongly contributed to-pedagogical and professional outcomes that likely benefit student engagement and achievement. The data strongly suggest that participants gain long-lasting personal and professional benefits from participation - value that seems to be especially magnified for mid- to late-career teachers who are well established in their teaching practices but committed to continuous improvement. On surveys administered immediately after each RET program, teachers report significant personal and professional benefits from participating. Self-report data from this study demonstrate that, for most teachers, RET effects last years - even decades - beyond the initial RET 
experience.

What program features account for these positive outcomes? While it was beyond the scope of this study to investigate the causes of the outcomes cited, the authors believe the RET model itself produces many of these results. Key components (common to most RET programs) seem designed to:

1. Provide experiences of significant duration (minimum six weeks, with eight weeks or two summers even better);

2. Engage teachers in authentic research as contributors, not observers;

3. Assign research projects for which teachers can take ownership; and

4. Provide ongoing support for curriculum development to ensure teachers can successfully connect their summer laboratory experiences to their classrooms/students.

As encouraging as these findings are, we do not believe that the Stanford program is anomalous. If these results accrue as we speculate above, similar findings could be expected from RET programs across the country. We urge the NSF to fund a program-level study to see whether these outcomes are consistent, and if so, whether teacher self-reports are validated by classroom observations and student reports. RET programs, by design, may include elements that are critical to successful teacher professional development. Confirming the generalizability of the Stanford RET alumni survey could broaden the impact of teacher professional development and enhance STEM students' engagement and achievement nationwide.

\section{AUTHOR INFORMATION Corresponding Author}

Kaye Storm. Stanford University, Office of Science Outreach, 450 Serra Mall, Building 160, Room 231, Stanford, CA 94305-2063

\section{Author Contributions}

The manuscript was written through contributions of all authors. All authors have given approval to the final version of the manuscript.

\section{FUNDING SOURCES}

This study was funded by Stanford University, with no external funding.

Stanford's RET programs were funded by the National Science Foundation RET Site Awards \#908516, \#1265721 and \#1760810 as well as other NSF awards to Stanford research centers and individual Principal Investigators. Other funders of the Summer Research Program for Teachers in- clude the Board of Supervisors of San Mateo County, the Howard Hughes Medical Institute, the National Institutes of Health, the Gordon and Betty Moore Foundation, NASA and the Camille and Henry Dreyfus Foundation.

\section{ACKNOWLEDGMENTS}

Grateful acknowledgement to Dr. Sheri Sheppard, Professor of Mechanical Engineering and Principal Investigator for Stanford's three RET Site Awards and to the National Science Foundation for awarding grants (\#908516, $\# 1265721$ and \#1760810) to support the program. The authors are also grateful to anonymous reviewers whose comments improved this paper.

\section{ABBREVIATIONS}

IISME: Industry Initiatives for Science and Math Education; RET: Research Experience for Teachers; UATIA: University of Arizona Teachers in Industry program

\section{REFERENCES}

Adnot, M., Dee, T., Katz, V., and Wyckoff, J. (2017). Teacher turnover, teacher quality, and student achievement in DCPS. Educational Evaluation and Policy Analysis, 39(1), 54-76.

American Association for the Advancement of Science. (1994). Benchmarks for science literacy. Oxford University Press.

Autenrieth, Robin L., Lewis, Chance W., and Butler-Purry, Karen L. (2017). Long-Term Impact of the Enrichment Experiences in Engineering (E3) Summer Teacher Program. Journal of STEM Education: Innovations and Research, $18(1), 25-31$

Blanchard, M. R., Southerland, S. A., and Granger, E. M. (2009). No silver bullet for inquiry: Making sense of teacher change following an inquiry-based research experience for teachers. Science Education, 93, 322-360.

Boyd, D., Grossman, P., Lankford, H., Loeb, S., and Wyckoff, J. (2008). Who Leaves? Teacher Attrition and Student Achievement, NBER Working Paper No. 14022, National Bureau of Economic Research.

Buxner, S. (2018). Teachers in Industry Annual Report University of Arizona (Unpublished data).

Bybee, R. W. (2004). Scientific inquiry and science teaching. In L. B. Flick, and N. G. Lederman (Eds.), Scientific inquiry and nature of science: Implications for teaching, learning, and teacher education (Chap. 1, pp. 1-14). Dordrecht, the Netherlands: Kluwer Academic Publishers.

California Department of Education, Education Data Partnership, https://www.ed-data.org/, accessed 2.7.18.

Carver-Thomas, D., and Darling-Hammond, L. (2017). Teacher turnover: Why it matters and what we can do about it (brief). Palo Alto, CA: Learning Policy Institute. 
Dubner, J., Silverstein, S. C., Carey, N., Frechtling, J., Busch Johnsen, T., Han, J., Ordway, G., Hutchinson, N., Lanza, J., Winter, J., Miller, J., Ohme, P., Rayford, J., Sloane Weisbaum, S., Storm, K., and Zounar, E. (2001). Evaluating science research experience for teachers programs and their effects on student interest and academic performance: A preliminary report of an ongoing collaborative study by eight programs. MRS Proceedings, 684(1), GG3-6.

Enderle, P., Dentzau, M., Roseler, K., Southerland, S., Granger, E., Hughes, R. and Saka, Y. (2014). Examining the influence of RETs on science teacher beliefs and practice. Science Education, 98, 1077-1108.

Goldring, R., Taie, S., and Riddles, M. (2014). Teacher Attrition and Mobility: Results From the 2012-13 Teacher Follow-up Survey (NCES 2014-077). U.S. Department of Education. Washington, DC: National Center for Education Statistics. Retrieved 12.17.18 from http://nces.ed.gov/ pubsearch.

Gray, L., and Taie, S. (2015). Public School Teacher Attrition and Mobility in the First Five Years: Results From the First Through Fifth Waves of the 2007-08 Beginning Teacher Longitudinal Study (NCES 2015-337). U.S. Department of Education. Washington, DC: National Center for Education Statistics. Retrieved 4.2.18 from http://nces.ed.gov/ pubsearch.

Helms-Lorenz, M., van de Grift, W., and Maulana, R. (2016). Longitudinal effects of induction on teaching skills and attrition rates of beginning teachers. School Effectiveness and School Improvement, 27(2), 178-204.

Herrington, D. G., Bancroft, S. F., Edwards, M. M., and Schairer, C. J. (2016). I want to be the inquiry guy! How research experiences for teachers change beliefs, attitudes, and values about teaching science as inquiry. Journal of Science Teacher Education, 27(2), 183-204.

Klein-Gardner, Stacy S., Johnston, Megan E., and Benson, Lisa (2012). Impact of RET teacher-developed curriculum units on classroom experiences for teachers and students," Journal of Pre-College Engineering Education Research (J-PEER), 2(2). https://doi.org/10.5703/1288284314868

Lindqvist, P., Nordänger, U. K., and Carlsson, R. (2014). Teacher attrition the first five years-A multifaceted image. Teaching and Teacher Education, 40, 94-103.

National Research Council. (1996). National science education standards. National Academies Press.

National Research Council. (2000). Inquiry and the national science education standards: A guide for teaching and learning. National Academies Press.

National Research Council. (2012). A framework for K-12 science education: Practices, crosscutting concepts, and core ideas. National Academies Press. (See Appendix F.) Accessed Decemeber 19, 2018.

National Science Foundation (2011). Research Experiences for Teachers (RET) in Engineering and Computer Science. Program Solicitation. Available at https://www.nsf.gov/ pubs/2011/nsf11509/nsf11509.htm\#toc. Accessed May $27,2018$.
Pop, M., Dixon, P., and Grove, C. (2010). Research Experiences for Teachers (RET): Motivation, expectations, and changes to teaching practices due to professional program involvement. Journal of Science Teacher Education, 21 (2), 127-147.

Russell, S. H., and Hancock, M. P. (2007). Evaluation of the Research Experiences for Teachers (RET) Program: 20012006, SRI International.

Southerland, S. A., Gess-Newsome, J., and Johnston, A. (2003). Portraying science in the classroom: The manifestation of scientists' beliefs in classroom practice. Journal of Research in Science teaching, 40(7), 669-691.

Watlington, E., Shockley, R., Guglielmino, P., and Felsher, R. (2010) The high cost of leaving: An analysis of the cost of teacher turnover, Journal of Education Finance, 36(1), 22-37.

Westerlund, J. F., Garci'a, D. M., Koke, J. R., Taylor, T. A., and Mason, D. S. (2002). Summer scientific research for teachers: The experience and its effect. Journal of Science Teacher Education, 13, 63-83.

Weisbaum, K.S. and Huang, D. (2001). IISME Teacher Retention and Program Impact 1985 - 2000, accessed 10.28 .18 at https://iisme.org/sites/default/files/TeacherRetentionStudy.pdf.

Windschitl, M. (2004). Folk theories of "inquiry:" How preservice teachers reproduce the discourse and practices of an atheoretical scientific method. Journal of Research in Science Teaching: The Official Journal of the National Association for Research in Science Teaching, 41(5), 481-512. 